\title{
Early life nutrition, the developing immune system and subsequent allergic manifestations
}

\author{
JLP Protudjer", GP Sevenhuysen, CD Ramsey, JM McGavock, AB Becker \\ From Canadian Society of Allergy and Clinical Immunology Annual Scientific Meeting 2009 \\ Halifax, Canada. 22-25 October 2009
}

Over the last half-century, chronic disease incidence, including allergic manifestations (AM), has increased exponentially in developed nations and amongst the wealthy in developing nations. Concurrently, there has been a "nutrition transition" in the same populations. Dietary patterns have shifted from a prudent diet (high fruit and vegetable-, and omega- 3 fatty acid intake; low omega- 6 fatty acid intake) to a western-style diet (higher levels omega- 6 fats, lower amounts of fresh fruits and vegetables, and omega-3 fats). While diet can impact health at any life stage, it is likely to be most important during the fetal and infancy periods, when the immune system is immature. Based on an extensive review of the literature, we considered this hypothesis for the 3 nutritional progressions from fetal life through infancy: prenatal nutrition, breastfeeding and introduction of solid foods. While there is little conclusive evidence to support that a prudent diet is protective against AM especially after birth, modest evidence suggests that a prenatal maternal nutrition high in $\mathrm{n}-3$ and micronutrients (e.g. vitamins $C, D$ and $E$ ) protect against AM. This indicates that there may be a window of opportunity during fetal development in which allergic manifestation risk may be altered. The effect of breastfeeding on the prevention AM is unresolved. Despite this, exclusive breastfeeding to 4-6 months should be encouraged as human milk contains numerous immunological properties and is associated with other health benefits. If breastfeeding is not possible, hydrolyzed formulas seem to confer a greater protective effect than traditional formulas. Solid foods should be introduced at age 4-6 months. The order of introduction seems to have little effect on AM. At present, it is impossible to conclusively state that a particular dietary pattern or food will alter

\footnotetext{
* Correspondence: jprotudjer@mich.ca

504J John Buhler Research Centre, 715 McDermot Avenue, Winnipeg, MB, Canada R3E 3P4
}

AM risk in infants. Implications for research and practice are also discussed.

Published: 12 May 2010

doi:10.1186/1710-1492-6-S1-P3

Cite this article as: Protudjer et al:: Early life nutrition, the developing immune system and subsequent allergic manifestations. Allergy, Asthma \& Clinical Immunology 2010 6(Suppl 1):P3.

\section{Submit your next manuscript to BioMed Central and take full advantage of: \\ - Convenient online submission \\ - Thorough peer review \\ - No space constraints or color figure charges \\ - Immediate publication on acceptance \\ - Inclusion in PubMed, CAS, Scopus and Google Scholar \\ - Research which is freely available for redistribution \\ Submit your manuscript at www.biomedcentral.com/submit}

